\title{
Barriers to and determinants of the choice of crop management strategies to combat climate change in Dejen District, Nile Basin of Ethiopia
}

\author{
Zerihun Yohannes Amare ${ }^{1 *}$, Johnson O. Ayoade², Ibidun O. Adelekan² and Menberu Teshome Zeleke ${ }^{3}$
}

\begin{abstract}
Background: Climate change without adaptation is projected to impact strongly the livelihoods of the rural communities. Adaptation to climate change is crucial for least developed country like Ethiopia due to high population and dependency on agriculture. Hence, this study was initiated to examine the barriers to and determinants of the choice of crop management strategies to combat climate change. The Intergovernmental Panel on Climate Change concepts of climate change response provided the framework. Stratified and snowball sampling techniques were employed to select a sample of 398 households. The household survey was employed to collect data on current adaptation strategies. Logistic regression was used to analyse the determinants of the choice of adaptation strategies. Logistic regression analyses were carried out at $p \leq 0.05$.

Results: Small farmland size, agro-ecology, farmland location, financial constraints, and lack of skills were the major barriers to adoption of crop management strategies. Age, farming experience, income, family size, government experts' extension services, agro-ecology setting, and crop failure history of households significantly affect the choice of most of the crop management strategies.

Conclusions: Socio-economic and institutional factors determined rural communities' ability and willingness to choose effective adaptation strategies. Policy priority should be given based on agro-ecology and households demand of policy intervention such as providing extension services and subsidizing the least adopted strategies due to financial constraints.
\end{abstract}

Keywords: Adaptation, Climate change impact, Crop management practices, Nile Basin of Ethiopia

\section{Background}

The warming trends observed over the past few decades continued in 2014. World Meteorological Organization (WMO) has ranked as nominally the warmest year since modern instrumental measurements began in the mid1800s [1]. The global average near-surface temperature for 2014 was comparable to the warmest years in the 165 -year instrumental record. In 2014, the global average temperature was $0.57 \pm 0.09^{\circ} \mathrm{C}$ above the $1961-1990$

\footnotetext{
*Correspondence: Zerihun.yohannes19@gmail.com

${ }^{1}$ Institute of Disaster Risk Management and Food Security Studies, Bahir Dar University, BahirDar, Ethiopia

Full list of author information is available at the end of the article
}

average of $14{ }^{\circ} \mathrm{C}$. It was $0.08{ }^{\circ} \mathrm{C}$ above the average anomaly of $0.50^{\circ} \mathrm{C}$ for the past 10 years (2005-2014) [1].

According to Food and Agricultural Organization [2], due to climate change and variability almost one billion people experienced hunger in 2010 globally. This implies the most marginalized people cannot access enough of the primary macronutrients. Perhaps, other billions are thought to suffer from hidden hunger, in which essential micronutrients are missing from their diet, with consequent risks of physical and mental impairment [3]. The majority (85\%) of the Ethiopian population is dependent on agriculture. As a result, agriculture will continue to be 
the most important sector in its need to adapt to climate change.

There are many reasons and convincing arguments for a more comprehensive consideration of adaptation as a response measure to climate change. Firstly, given the amount of past greenhouse gas emissions and the inertia of the climate system, we are already bound to some level of climate change, which can no longer be prevented even by the most ambitious emission reductions [4]. Second, the effect of emission reductions takes several decades to fully manifest, whereas most adaptation measures have more immediate and sustainable benefits [5].

Third, adaptations can be effectively implemented on a local or regional scale such that its efficiency is less dependent on the actions of others, whereas mitigation of climate change requires international cooperation. Fourth, most adaptations to climate change also reduce the risks associated with current climate variability, which is a significant hazard in many world regions. According to Gbetibouo [6], there are two adaptation assessment approaches, namely top-down and bottomup assessment approaches. The top-down approach starts with climate change scenarios, and estimates impact through scenario analysis, based on which possible adaptation practices are identified. Most of the top-down adaptations represent possible or potential measures, rather than those that have been used [6].

Most studies, e.g. [7-9], carried out in Ethiopia and Africa using top-down approach predicted the impact of climate change on the agricultural sector with adverse effects on crop yields. The bottom-up approach takes a vulnerability perspective where adaptation strategies are considered more as a process involving the socio-economic, and policy environments, and elements of decision-making [6]. In line with this notion, Schröter et al. [10] argue that in choosing adaptation options to climate change and developing policies to implement these possibilities the affected community should actively participate. This study adopts the bottom-up approach that seeks to identify actual adaptation strategies at the local level and the factors that determine the choice of crop management strategies in Dejen District, Nile Basin of Ethiopia.

\section{Methods}

\section{The study area}

The study district is located in west-central Ethiopia (Fig. 1) at a road distance of $335 \mathrm{~km}$ south of the regional state capital, Bahir Dar City, and $230 \mathrm{~km}$ northwest of the capital city of Ethiopia, Addis Ababa, in the Amhara Regional State at the edge of the canyon of the Blue Nile. The district lies between longitude $38^{\circ} 6^{\prime} \mathrm{E}$ and $38^{\circ} 10^{\prime} \mathrm{E}$, and between latitude $10^{\circ} 7^{\prime} \mathrm{N} 10^{\circ} 11^{\prime} \mathrm{N}$, with an elevation of 1071 and $3000 \mathrm{~m}$ above sea level (m.a.s.l). The average temperature and total annual rainfall of the district range between 20 and $24{ }^{\circ} \mathrm{C}$ and 800 and $1200 \mathrm{~mm}$, respectively. Dejen District is located in the valley of the Blue Nile which is highly undulated topography and frequent susceptibility to climate-related problems such as erratic rainfall, crop pests, livestock diseases, and malaria outbreaks. In the past 8 years (2009-2016) due to climate change impacts, the district loses 50,555 quintals of crops, which has the potential to feed 27,701 individuals. The study district is categorized into three agro-ecological zones, $41 \%$ Dega (highland), 31\% Woinadega (midland), and 28\% Kolla (lowland) [11, 12].

\section{Research design and sampling procedure}

The study employed cross-sectional research design with both quantitative and qualitative research methods. This study used a multi-stage sampling technique to select the agro-ecology, Kebeles (the lower administrative unit next to district), and households. At the first stage, Dejen District of the Nile Basin was selected purposely due to its highly undulated topography and frequent susceptibility to extreme events and representativeness of the three agro-ecological zones such as highland, midland, and lowland. In the second stage, six Kebeles (two from each agro-ecological setting) were selected purposely based on the above-listed district selection criteria.

Climate change affects the rural communities differently in different agro-ecological zones. As a result, communities' knowledge and skill to adapt to the climate change impacts varies from different agro-ecological settings. In the third stage, stratified sampling was employed to select households. Under the stratified sampling, the population was divided into male- and female-headed households, and then the sample was selected from each male- and female-headed household to constitute a representative sample.

The sample size was determined proportionately (Table 1). In Ethiopia context, female-headed households are those who do not have husband due to either being divorced, widowed, or separated. In Ethiopia, in some of the rural communities, disclosing of the marital status of older females is culturally not feeling comfort them. Thus, to get female-headed households, snowball sampling was employed. Based on Yamane [13] at the 95\% confidence interval and 5\%, level of precision, 398 households were selected at the six Kebeles of the district (Table 1).

\section{Data sources and data collection methods}

The primary and secondary data sources were quantitative and qualitative in nature. The study used two main data sources to analyse the barriers and determinants of the adoption of crop management strategies to climate 


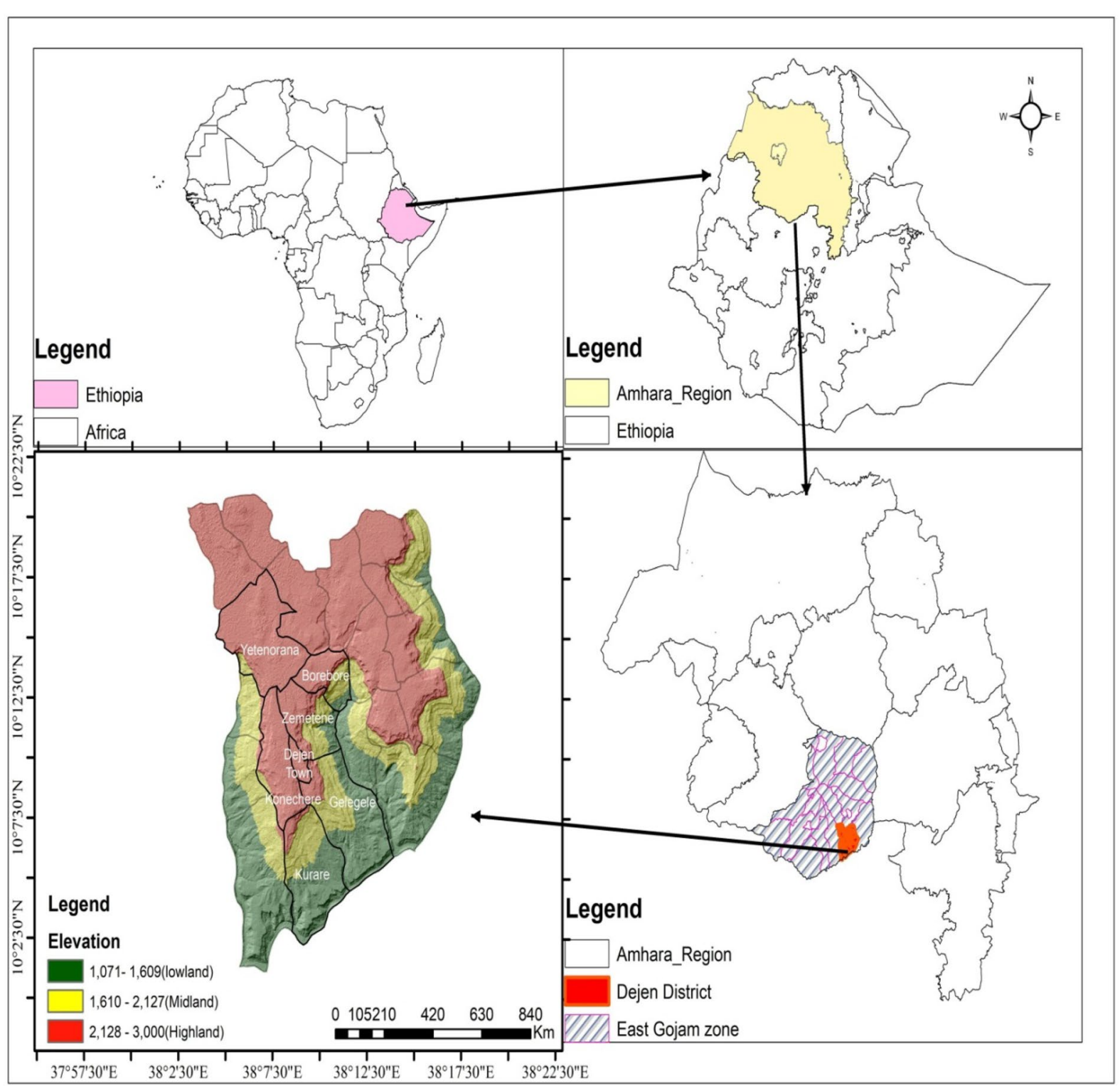

Fig. 1 Study area

change impacts. The main data source was the socio-economic data collected through household survey.

\section{Household survey}

The household survey was used to collect quantitative data on households' current adaptation strategies, the barriers to adapt, and factors that affect rural communities' choice of crop management strategies. The survey questions were prepared in English language. It was translated into local language (Amharic) during data collection and then encoded into SPSS in English language for data processing and analysis. The household survey was initially pretested to check the appropriateness and validity of the questions from the three agro-ecological zones. Pretested Kebeles and participant households were not involved in the actual survey.

After pretesting, ambiguous words were rephrased and inappropriate questions were modified. The experience of the author in the study area played a paramount role in choosing the data collectors who have been working for many years in the rural community in the field of agriculture, environment, and land administration. The data were collected by the trained data 
Table 1 Distribution of sample size based on the total study population. (Source: computed based on [14])

\begin{tabular}{|c|c|c|c|c|c|}
\hline \multirow[t]{2}{*}{$\begin{array}{l}\text { Sample } \\
\text { Kebeles }\end{array}$} & \multicolumn{3}{|c|}{$\begin{array}{l}\text { Number } \\
\text { of household heads }\end{array}$} & \multirow[t]{2}{*}{$\begin{array}{l}\% \text { of study } \\
\text { population }\end{array}$} & \multirow[t]{2}{*}{$\begin{array}{l}\text { Share of Kebeles } \\
\text { from } 398 \mathrm{HHs}\end{array}$} \\
\hline & Male & Female & Total & & \\
\hline $\begin{array}{l}\text { Koncher (high- } \\
\text { land) }\end{array}$ & 995 & 225 & 1220 & 16.5 & 66 \\
\hline $\begin{array}{l}\text { Yetnora (high- } \\
\text { land) }\end{array}$ & 1388 & 767 & 2155 & 29 & 115 \\
\hline $\begin{array}{l}\text { Zemeten (mid- } \\
\text { land) }\end{array}$ & 652 & 280 & 932 & 12.6 & 50 \\
\hline $\begin{array}{l}\text { Borebor (mid- } \\
\text { land) }\end{array}$ & 644 & 281 & 925 & 12.5 & 50 \\
\hline Kurar (lowland) & 726 & 363 & 1089 & 14.7 & 59 \\
\hline \multirow{2}{*}{$\begin{array}{l}\text { Gelgele (low- } \\
\text { land) }\end{array}$} & 732 & 345 & 1077 & 14.6 & 58 \\
\hline & 5137 & 2261 & 7398 & 100 & 398 \\
\hline
\end{tabular}

HHs Households

collectors under close supervision of the author in the period March to October 2016.

\section{Methods of data analysis}

The descriptive statistics such as percentage and frequencies were used to summarize and categorize the information gathered from households. The binary logistic regression was used to analyse determinants of the choice of crop management strategies.

Before the data collection, a multinomial logistic (MNL) model was proposed based on aspects of the literature. However, in the course of this study, the surveyed households chose more than one adaptation strategies simultaneously. As a result, the use of multinomial logistic regression was inappropriate. To fix such problems, the possible remedy suggested by Bryan et al. [15] was to combine similar measures into single categories. However, such grouping into self-defined categories may lead to miss interpretation $[15,16]$. Besides, the set of explanatory variables affecting the households' decision was also expected to be different for different adaptation strategies. Therefore, this study employed binary logistic regression technique to analyse the determinants of the choice of crop management strategies. Analysis of the logistic regression of binary response model can be defined as:

$y=\frac{1}{e^{-[\beta 0+\beta 1(x 1)+\beta 2(x 2)+\beta n(x n)}} e^{\beta 0+\beta 1(x 1)+\beta 2(x 2)+\beta 3(x 3)+\beta n(x n)}$,

where $y$ is response variable; $y=1$, outcome is present (adopt); $y=0$, outcome is not present (not adopt); $\beta_{0}$ is constant.

$\beta_{1}+\beta_{2}+\beta_{3}+\cdots \beta_{n}$ are regression coefficients that explain the change in the log odds for each unit change in $x . x_{1}+x_{2}+\cdots x_{n}=$ set of predictor variables included in the model (Table 2). $e^{\beta}$ represents the change in the odds of the outcome (multiplicatively) by increasing $x$ by 1 unit. The current crop management adaptation strategies in the study area, such as using crop diversification, improved seeds, changing planting date, and replanting failed crops, were used as dependent variables. The choices of these adaptation strategies were determined by socio-economic and demographic characteristics, institutional factors, and agro-ecological settings (Table 2). Based on Agresti [17], logistic regression method can be used when the dependent variable $Y$ is dichotomous. $Y$

Table 2 Description of explanatory variables that affect households' choice of crop management strategies. Source: Author (2016)

\begin{tabular}{ll}
\hline Explanatory variables & Description \\
\hline Sex & Dummy, $1={ }^{a}$ Male, $0=$ Female \\
Age & Discrete (years), ${ }^{a} 18-35,36-55,>55$ \\
Education & Discrete (years), ${ }^{a}$ Cannot read and write, primary school and above) \\
Farming experience & Continuous (years), ${ }^{a} 10,10-20,21-30,>30$ \\
Income & Continuous (ETB), ${ }^{a}<10,000,10,001-30,000,30,001-50,000,>50,000$ \\
Family size & Discrete (number), ${ }^{a}<4$, and $>4$ \\
Access to weather information & Dichotomous, $1={ }^{a}$ Yes, $0=$ No \\
Access to farmer to farmer extension services & Dichotomous, $1={ }^{a}$ Yes, $0=$ No \\
Access to government experts' extension services & Dichotomous, $1={ }^{a}$ Yes, $0=$ No \\
Agro-ecology settings & Dummy, $1={ }^{a}$ highland; $2=$ midland; $3=$ lowland \\
Farmland size & Continuous (hectare), ${ }^{a}<1.2$, and $>1.2$ \\
Crop failure history of households & Dichotomous, $1={ }^{a}$ Yes, $0=$ No
\end{tabular}

a Taken as reference (base for analysis), ETB is Ethiopian currency $(\$ 1=22.3 \mathrm{ETB})[18]$ 
is coded as 1 when the outcome is present and coded 0 when the outcome is not present.

\section{Test of goodness of fit and multicollinearity}

The fitness of the logistic regression model to the data was measured by using the SPSS classification table (crosstabs) and the Hosmer-Lemeshow test. Besides, collinearity among predictor variables was checked using multicollinearity statistics. The Hosmer-Lemeshow test used $95 \%$ confidence interval (CI) and asymptotically follows a $X^{2}$ distribution.

Empty cells or small frequency was checked by doing crosstabs between categorical predictor variables and the outcome variables. When the cell has very few cases, the model becomes unstable. Based on Kothari [19] and SPSS [20], the Hosmer-Lemeshow statistics indicate a poor fit if the significance value $(p)$ is less than 0.05 (Table 3).

Techniques to remedy poor fit of the model were by: (1) using re-categorized (for example educational levels were categorized as cannot read and write and primary school level and above), (2) dropping the least theoretically important explanatory variables that contribute to the model a poor fit to the data. For example, explanatory variables such as family size and crop failure history of households were excluded from entering and competing in the model in the improved seed and crop diversification adaptation options, respectively.

In the logistic regression model, the Exp (B) is the "Odds ratio" which explains the effect of the independent variable $\left(X_{n}\right)$ on the dependent variable. The beta coefficient $(\beta)$ is the estimated logit coefficient which is the rate of change in the $Y$ (the dependent variables) as $X$ (independent variable) changes. When the beta coefficient $(\beta)$ is negative, it shows that the dependent and independent variables have an inverse relationship, and when it has a positive coefficient, there is a positive relationship. Odds ratio $=1$ indicates the same probability of an event occurring between the two situations. Odds ratio $>1$ probability of an event occurring with a unit increase in the independent variable is higher than the reference/base variable. Odds ratio $<1$ probability of an event occurring with a unit increase in the

Table 3 Hosmer and Lemeshow goodness-of-fit test results of logistic regression model. (Source: Computed based on household survey data, March-October (2016))

\begin{tabular}{lccl}
\hline Dependent variables & Chi-square & $\boldsymbol{d f}$ & $\boldsymbol{P}$ value $(>\mathbf{0 . 0 5})$ \\
\hline Crop diversification & 7.763 & 8 & 0.457 \\
Improved seeds & 10.78 & 8 & 0.214 \\
Changing planting date & 9.239 & 8 & 0.323 \\
Replanting failed crops & 2.416 & 8 & 0.966 \\
\hline
\end{tabular}

$d f$ degree of freedom independent variable is lower than the reference/base variable (Table 2).

Multicollinearity was assessed by examining tolerance and variance inflation factors (VIF). The variance inflation factor (VIF) quantifies how much the variance is inflated. The tolerance is the percentage of the variance in a given predictor that cannot be explained by the other predictors. When VIF $>5, X$ (the explanatory variable) is highly correlated with the other explanatory variables $[20,21]$. Mathematically, variance inflation factor (VIF) can be expressed by:

$\mathrm{VIF}=\frac{1}{1-R^{2} j}$, where $R^{2} j$ is the coefficient of determina-

tion of a linear regression model that uses $X_{i}$ as the response variable and all other $X$ variables as the explanatory variables. Tolerance is the reciprocal of VIF (i.e. tolerance $=\frac{1}{\mathrm{VIF}}$ ). A tolerance of less than 0.20 and/or a variance inflation factor (VIF) greater than 5 and above indicates a multicollinearity problem. However, in this study, the results of the variance inflation factor indicated that there was no multicollinearity problem.

\section{Results}

\section{Barriers to crop management strategies}

Implementation of crop management strategies used by the rural communities varied among households. The study identified a number of constraints faced by the households to adopt crop management strategies to combat climate change impact.

\section{Crop diversification}

The major constraints identified by respondents to not to adopt crop diversification were: small land size (57\%) followed by soil fertility decrement (25.3\%), shortage of money to buy some expensive crop varieties (1.3\%), shortage of labour $(2.5 \%)$ to implement some labourintensive farming practices, and they prefer the easiest crop type, lack of skill (3.8\%) to sow different crops and stick to one types of crop, topography of farmland location $(2.5 \%)$ which permits only some crop types to grow, and the remaining $(2.5 \%)$ do not/have small land size. The majority $(58 \%)$ of rural communities have less than 1.2 hectares. As a result, small land size/no land at all consequences is barrier to the choice of crop management strategies. On the other hand, rural communities who are located in the lowlands of the undulated topography encountered farm soil fertility decrement. Due to this reason, farmers were obliged to leave their farmland (fallowing) for some periods instead of diversifying different crops as an adaptation strategy to climate change. 


\section{Improved seeds}

The study communities adopt improved seeds (84.4\%). However, the remaining households did not use improved seeds for one or another reason: financial constraints (42.6\%), lack of skills (18\%) on how to use, compatibility problems with their farmland (16.4), small/no land at all (13.1\%), and lack of information (9.8\%). Rural communities need all the support they can get to fight the adverse impacts of climate change and extreme weather events. Improved seed varieties developed by research institutes offer higher yields and stronger resistance to challenges related to climate change such as drought. Improved seed tolerates weeds and other climate change-related diseases.

\section{Changing planting dates}

Planting dates are growing season during which the rainfall and temperature allow plants to grow. Among interviewed households, $78.9 \%$ used changing planting dates, whilst others do not use this method. Among those who did not use changing planting dates, $87.6 \%$ of the respondents attributed lack of skills as a barrier to adaptation methods, whilst $12.3 \%$ have not/small land size.

\section{Replanting damaged crops}

Weather events such as flooding, hailstorms, disease outbreaks can damage previously planted crops in all or a portion of farm fields. This requires technical assistance for decision-making in replanting. The majority $(92.5 \%)$ of respondents replant their failed crops. However, among those who did not use, the majority (63\%) of households indicated lack of skills about future weather forecast and economic return of the replanting crops, suitability of land and cropping season (7.4\%) and small land size/no land (29.6\%) contributes for not using replanting damaged crops.

Determinants of the choice of crop Management strategies The determinant factors of the choice of adaptation strategies are presented in Table 2 . Analyses were carried out at $p \leq 0.05$.

Changing crop management practice is one of the adaptation practices to climate change impacts. For this study using crop diversification, improved seeds, changing planting date, and replanting failed crops were selected in the context of the study sites. The applications of these strategies have been determined by a number of socio-economic, biophysical, and institutional factors (Table 4).

\section{Age of the household head}

Crop diversification is considered as an important adaptation strategy to combat climate change impacts. The logistic regression model results indicated that adultheaded households have a significant $(p=0.010)$ effect on adopting crop diversification (Table 4). This means adult household heads (age 36-55) are 3.506 times more likely to use crop diversification than young-headed households (age 18-35). Adult-headed households (36-55) have a significant $(p=0.010)$ effect on adopting improved seeds $(p=0.011)$. The beta coefficient $(+1.415)$ shows positive relationships in explaining adopting improved seeds. This indicates there is an increase in the log of odds using improved seeds by 1.415 in adult-headed households (HHH1). Exp (B) of 4.115 indicates that adult-headed households are 4.115 times more likely to use improved seeds than young- and old-headed households. Oldheaded households have a significant $(p=0.038)$ effect on adopting changing planting date (age $>55$ years) $(\mathrm{HHH} 2)$; $\operatorname{Exp}(B)$ of 5.985 indicates 5.985 times more likely to adopt changing planting date than (age 18-35). This indicates that, as age increases, the probability of adopting changing planting date as adaptation strategy increased.

Adult- and old-headed households have a significant $(p=0.005 ; 0.014)$ power in explaining replanting failed crops. Age shows positive relationship (Beta $=\mathrm{HHH} 1$, +1.689 and $\mathrm{HHH} 2,+3.470)$. This indicates that there is an increase in the log of odds by 1.689 and 3.470 . Adultheaded households (HHH1) Exp $(B)$ of 5.416 indicate 5.4416 times more likely, and old-headed households $(\mathrm{HHH} 2) \operatorname{Exp}(B)$ of 32.143 times much more likely to use replanting their failed crops than young-headed households (age 18-35 years). The possible explanation is that age of household head increases the possibility of pursuing replanting failed crops as climate change adaptation strategy.

\section{Farming experience}

Farmers in the range of farming experience 10-20 years $(\mathrm{HHH} 1)$ have a significant effect on adopting improved seeds $(p=0.000)$. The beta coefficient indicates positive relationships in adopting improved seeds. This implies there is an increase in the log of odds by 2.319 in using improved seeds. The EXP $(B)$ of 10.166 indicates that households having farming experience of 10-20 ( $\mathrm{HHH} 2)$ are 10.166 times more likely to adopt improved seeds than households having farming experience of fewer than 10 years $(\mathrm{HHH}), 21-30$ years $(\mathrm{HHH} 2)$, and $>30$ years (HHH3).

The farming experience of 21-30 years and $>30$ years has a significant effect $(p=0.007$ and 0.018$)$ on adopting changing planting date. Farming experience of 21-30 years $(\mathrm{HHH} 2$, Beta $=-1.567)$ and $>30$ years $(\mathrm{HHH} 3$, Beta $=-1.659)$ indicates that there is a decrease in the log of odds by 1.567 and 1.659 (inverse relationships). The $\operatorname{Exp}(B)$ of 0.209 and 0.190 indicates farming 
Table 4 Determinants of households' choice of crop management strategies to climate change impact. (Source: Computed from household survey, March-October (2016))

\begin{tabular}{|c|c|c|c|c|c|c|c|c|}
\hline \multirow[t]{2}{*}{ Explanatory variables } & \multicolumn{2}{|c|}{ Crop diversification } & \multicolumn{2}{|c|}{ Improved seed } & \multicolumn{2}{|c|}{ Changing planting dates } & \multicolumn{2}{|c|}{$\begin{array}{l}\text { Replanting failed } \\
\text { crops }\end{array}$} \\
\hline & $p$ & $\operatorname{Exp}(B)$ & $p$ & $\operatorname{Exp}(B)$ & $p$ & $\operatorname{Exp}(B)$ & $p$ & $\operatorname{Exp}(B)$ \\
\hline Sex_HHH (1) & .170 & 1.850 & .983 & .991 & .055 & .376 & .104 & .332 \\
\hline Age_HHH & .035 & & .039 & & .102 & & .008 & \\
\hline Age_HHH (1) & $.010^{*}$ & 3.506 & $.011^{*}$ & 4.115 & .092 & 2.360 & $.005^{*}$ & 5.416 \\
\hline Age_HHH (2) & .110 & 3.662 & .111 & 3.886 & $.038^{*}$ & 5.985 & $.014^{*}$ & 32.143 \\
\hline Edu_HHH (1) & .731 & 1.149 & .226 & 1.690 & .725 & .867 & .456 & 1.513 \\
\hline Farm_exp_HHH & .233 & & .004 & & .046 & & .603 & \\
\hline Farm_exp_HHH (1) & .108 & 2.384 & $.000^{*}$ & 10.166 & .120 & .428 & .261 & 2.246 \\
\hline Farm_exp_HHH (2) & .884 & .917 & .238 & 2.100 & $.007^{*}$ & .209 & .496 & 1.796 \\
\hline Farm_exp_HHH (3) & .533 & .636 & .078 & 3.943 & $.018^{*}$ & .190 & 880 & .864 \\
\hline Income_HHs & .000 & & .013 & & .097 & & .697 & \\
\hline Income_HHs (1) & $.000^{*}$ & 8.481 & $.012^{*}$ & 3.408 & .639 & 1.378 & .558 & 1.490 \\
\hline Income_HHs (2) & $.000^{*}$ & 17.510 & $.029^{*}$ & 3.632 & .051 & 4.163 & .241 & 2.701 \\
\hline Income_HHs (3) & $.000^{*}$ & 18.539 & $.002^{*}$ & 9.064 & .281 & 2.275 & .444 & 1.998 \\
\hline Family_size_HHs (1) & .820 & .902 & $\mathrm{~N} / \mathrm{C}$ & $\mathrm{N} / \mathrm{C}$ & .416 & 1.490 & $.002^{*}$ & .101 \\
\hline Weather_info_HHH (1) & .364 & .668 & .182 & .526 & .102 & .533 & .774 & .848 \\
\hline Farmer to farmer extension (1) & .809 & 1.118 & .424 & 1.455 & .658 & .806 & .093 & 3.286 \\
\hline Government experts extension (1) & $.003^{*}$ & .271 & .635 & .815 & .124 & .520 & .064 & .290 \\
\hline Agro-ecol._HHs & .005 & & .000 & & .000 & & .022 & \\
\hline Agro-ecol._HHs (1) & $.036^{*}$ & 4.082 & .055 & 5.446 & $.002^{*}$ & 5.412 & .200 & 2.922 \\
\hline Agro-ecol._HHs (2) & .093 & .496 & $.002^{*}$ & .218 & $.000^{*}$ & 145.815 & $.006^{*}$ & 11.247 \\
\hline Farmlandsize (1) & $.001^{*}$ & 4.286 & .865 & .931 & $.000^{*}$ & .150 & $.02^{*}$ & 4.570 \\
\hline Crop failure & $\mathrm{N} / \mathrm{C}$ & $\mathrm{N} / \mathrm{C}$ & .205 & 1.656 & $.044^{*}$ & .345 & .211 & 0.146 \\
\hline Constant & .121 & .245 & .305 & .347 & .002 & 23.795 & .894 & 1.196 \\
\hline
\end{tabular}

$\mathrm{N} / \mathrm{C}$ not computed, $\mathrm{HHH}$ household head, $\mathrm{HH}$ s households

*Significant at 0.05

experience of (HHH2) only 0.209 times and (HHH3) only 0.190 times (much less) likely to adopt changing planting date.

\section{Income}

Income has a positive and significant $(p=0.000)$ effect on adopting crop diversification. Exp (B) of income $(10,001-30,000) 8.481$ times, income $(30,001-50,000)$ 17.510 times, and income $(>50,000) 18.539$ times more likely to diversify crops than low-income groups $(<10,000)$. Income of households has a positive (Beta, $+1.226,+1.290$, and +2.204$)$ and significant $(p=0.012$, 0.029 , and 0.002 ) effect on adopting improved seeds. This indicates there is an increase in the log of odds by $1.226,1.290$, and 2.204 in adopting improved seeds as an adaptation strategy. The EXP $(B)$ of income (HHs1) 3.408 times, income (HHs2) 3.632 times, and income (HHs3) 9.064 times is more likely to adopt improved seeds than low-income households $(<10,000)$.

\section{Family size}

Family size has a significant $(p=0.002)$ effect on adopting replanting failed crops. Family size has an inverse (Beta $=-2.297)$ in the log of odds by 2.297. The Exp $(B)$ of 0.101 indicates households having family size $>4$, only 0.101 times (much less) likely to replant failed crops. The inverse of $\operatorname{Exp}(B)$ of 0.101 indicates small family sizes $(<4)$ are 9.91 times (much more) likely to replant failed crops than large family sizes.

\section{Access to government experts' extension services}

Formal extension services from government experts have a significant $(p=0.003)$ effect on adopting crop diversification to combat climate change impacts. The beta coefficient shows an inverse relation $(-1.306)$ in adopting adaptation strategies. This indicates households who did not get extension service; there is a decrease in the log of odd in diversifying crops by 1.306 . The Exp $(B)$ of 0.271 indicates that households who did not get formal extension services were only 0.271 times (i.e. much less) likely 
to diversify crops than households who have got extension service during 12 months of the year.

\section{Agro-ecology settings}

Significant variation in the adoption of crop diversification was observed across agro-ecological zones (midland, $p=0.036$ ). For example, higher crop diversification was identified in the midland than highland and lowland agro-ecological settings. The $\operatorname{Exp}(B)$ of 4.082 indicates households who live in the midland 4.082 times more likely to use crop diversification than households reside in highland. The $\operatorname{Exp}(B)$ of 0.496 indicates the lowland households are only 0.496 times much less likely diversifying crops than highlands. This means highland resident households are 2.016 times more likely to diversify crops than lowland households (i.e. invert, $1 / 0.496=2.016$ ).

The lowland agro-ecology with an inverse beta value $(-1.552)$ has a significant effect $(p=0.002)$ on adopting improved seeds. This indicates a decrease (1.522) in the log of odds on adopting improved seeds in the lowland agro-ecology zones. The EXP $(B)$ of 0.218 indicates the lowland households are only 0.218 times (much less) likely to use improved seeds than highland households. This indicates that highland households are 4.587 times (much more) likely to use improved seeds than lowland resident households (inverse of $1 / 0.218=4.587$ ).

The midland and lowland agro-ecologies have a significant effect on changing cropping date $(p=0.002$ and $p=0.000)$, respectively. The coefficient of beta $(+1.689$ midland (HHs1) and +4.982 lowland $(\mathrm{HHs} 2)$ ) indicates there is an increase in the log of odds by 1.689 and 4.982 on adopting changing planting date. The $\operatorname{Exp}(B)$ of 5.412 indicates that households who reside in the midland agro-ecology are 5.412 times much more likely to change their cropping date than highland households.

The mid- and lowland agro-ecologies have a significant $(p=0.006 ; 0.020)$ effect on adopting replanting failed crops. There is an increase (Beta $=+1.072$ midland (HHs2) and +2.420 lowland (HHs2)) in the log of odds by 1.072 and 2.420 . The $\operatorname{Exp}(B)$ of 2.922 indicates households who live in the midland agro-ecologies are 2.922 times more likely to use replanting than highland households. The $\operatorname{Exp}(B)$ of 11.247 indicates the lowland households are 11.247 times (much more) likely to replant their failed crops.

\section{Farmland size}

Farmland is the most significant $(p=0.001)$ factor to diversify crops in the study communities. The beta coefficient of households having farm size of $>1.2$ hectare has a positive relation to diversify crops. This implies there is an increase in the $\log$ of odds in diversifying crops by 1.455 . The Exp $(B)$ of 4.286 means households having farmland size $>1.2$ hectares are 4.286 times more likely to diversify crops than households with $<1.2$ hectare farmland. Farmland size ( $>1.2$ hectares) of households has an inverse (beta, -1.898 ) and significant $(p=0.000)$ effect on adopting changing planting date. This indicates a decrease (inverse relationships) in the $\log$ of odds by 1.898 in changing planting date. The Exp $(B)$ of 0.150 indicates households having large farmland size ( $>1.2$ hectares) are only 0.150 times changed their planting date. Households having small land size $(<1.2$ hectare) are 6.76 times more likely to use changing planting date. Farmland size has a positive relationship (Beta, +1.519) with no significant effect on adopting replanting failed crops. There is an increase in the log of odds by 1.519 . The $\operatorname{Exp}(B)$ of 4.570 indicates households having $>1.2$-hectare land are 4.2570 times more likely to replant failed crops than households with $<1.2$ hectares.

\section{Crop failure history of households}

Crop failure has a significant ( $p=0.044)$ effect on adopting changing planting date. Households who never faced crop failure in the past 10 years have an inverse relationship (Beta $=-1.064$ ) in employing changing planting date. The $\operatorname{Exp}(B)$ of 0.345 indicates households who never faced crop failure in the past 10 years are only 0.345 times adopted changing planting date. The invert of Exp $(B)$ of 0.345 is 2.8986 , which indicates households who faced crop failure are 2.8986 times more likely to change planting date. This implies most farmers learn only when they faced problems.

\section{Discussion}

The rural communities of Dejen District adopt crop management strategies to combat climate change impacts. However, the key barriers identified in the study district were shortage of money, lack of access to information, and small land size. Previous studies (e.g. [22-24]) stated that financial barriers are one of the barriers that restrict implementation of adaptation strategies. This implies every form of adaptation requires some direct or indirect costs. For instance, the use of improved varieties of crops has been reported as one of the key adaptation strategies for farmers in Dejen District, Nile Basin of Ethiopia, where this study confirmed. In the context of this study, improved seeds include high yielding varieties, drought tolerant, short maturing, pest- and disease-resistant species either induced or indigenous. When improved seed varieties are available, their price may be prohibiting making it difficult for many rural households to access. Thus, framers have often sought to use their own saved seeds. One of the possible causes of financial barriers in the study area could be due to lack of credit facilities to rural communities. 
Access to information on weather and climate change is an important tool that can be used to enhance the adaptation and implementation of adaptation strategies by rural communities of the study area. Access to information is particularly important for Africa [25] and Ethiopia in particular, where there are few climate projections due to lack of appropriate climate data. This is crucially important, considering that most farming systems in Dejen District depend on rain-fed agricultural systems. Hence, lack of appropriate climate information could be crucial for rural communities' food security.

Age of household heads significantly determined crop diversification, improved seeds and changing planting date, and replanting failed crops. Crop diversification and replanting of the failed crops require more energy and experience. Thus, adult household heads are more matured and active in sowing different crops than old and young household heads. The possible reason for the positive and significant association is due to the fact that age is the proxy indicator that may likely to endow the farmers with the requisite experience that enables them to make a better decision in the choice of crop management strategies. This is in line with studies by Deressa et al. [26] who found that an increase in age of household head does mean an increase in farming experience which would increase rural communities' local knowledge to respond to hazards resulted in climate change and variability.

Farming experience is one of the significant variables that affect the rural communities' choice of adaptation strategies. Farming experience is a proxy indicator of age. Like crop diversification, the middle age household heads have ability and willingness to adopt improved seeds to adjust climate change impacts. This implies as one become more experienced in farming, the probability of one to use improved seeds increases more than a farmer with less farming experience.

On the other hand, farming experience has an inverse relationship with changing planting date. The reason for an inverse relationship might be that experienced farmers will have access to irrigation and water harvesting for their agricultural activities and plant their seeds without changing the planting date. This implies a farmer with more experience would know when climate variability is occurring in the area and which method of adaptation strategies works well in that specific agro-ecology zone. As expected, income is positively and significantly associated with the household decision to pursue crop diversification and improved seeds. This means crop diversification and purchasing of improved varieties of seeds require money. This implies the rate of using crop diversification and improved seeds is increased as income of households increased.
Family size is negatively and significantly associated with the households' decision to pursue replanting failed crops. Households who have large family size are supposed to have an opportunity in pursuing various adaptation options to combat impacts of clime change and variability. This argument is raised by previous studies $[26,27]$ who argued that large family size is associated with higher labour endowment which would enable a household to accomplish various agricultural tasks. The possible reason for an inverse relationship might be due to the fact that community's expectation of the benefits of using adaptation strategy. In this regard, Barungi and Maonga [28] based on the rational choice theory; argue that the behaviour of human beings is motivated by the possibility of gaining benefit. The possible explanation could be households who have large family size have the possibility to engage in off-farm activities, and they will ignore the failed crops to replant. Therefore, rural communities are rationale consumers of new technologies, and they will only adopt technology as they foresee it will result in increased productivity.

Access to government extension services has a negative and significant association with the likelihood of choosing crop diversification to combat climate change impacts. This result is in contrary with previous studies $[29,30]$ who noted that farmers who obtain agricultural extension services through extension workers are more likely informed about the climatic situation and the responses followed. The contributing factors for this inverse relationship could be barriers to adopting crop diversification such as inadequate extension services, constraints of money, labour, skills, and farmland locations.

Households who live in the midland and highland agroecologies have a significant and positive effect on adoption of crop diversification. This is because the suitability of highland agro-ecology to sow different types of crops and access to government extension services due to proximity to the administration. For instance, in this study finding, the midland agro-ecology has got more access to extension services (77\%) than the lowland agro-ecology (47\%) communities by the government extension experts in the past cropping season.

The lowland agro-ecology resident households have a negative and significant effect on adoption of improved seed varieties. The possible explanation is that lowland households did not use improved seeds because of suitability problem of the lowland agro-ecology and topography to use improved seeds to their farmland. This was confirmed by households report on the barriers to adopt improved seeds as crop management strategy. On the other hand, the lowland agro-ecology has a positive and significant effect on pursuing changing planting dates 
to combat climate change impacts. This is because lowland agro-ecologies are characterized by erratic rainfall and other extreme events that lead households to change their planting date. The midland and lowland agro-ecologies have a significant effect on employing replanting failed crops as crop management strategy to combat climate change impacts. This is due to the fact that the midland and lowland households are characterized by climate variability such as erratic rainfall than the highland agro-ecology households. The exposure of climatic variability gave them more experience in adopting replanting their failed crops than highland households.

As expected, farm size has a significant and positive effect on adopting crop diversification to combat climate change impacts. Households with larger farm sizes were more likely to diversify their crops. On the other hand, larger farmland size has a negative and significant effect on using changing planting dates as crop management strategies. This means households having small land size $(<1.2$ hectares $)$ are more likely use changing planting dates. This reminds us "a hunter who has only one arrow does not shoot with careless aim". This implies households who have small land size took care of their farmland and changed their planting dates when there is a change in weather conditions. Even if farmland size has no significant effect on changing failed crops, it shows a positive effect on using changing failed crops. The possible explanation could be the more farmland plot they have, the more is the probability of having failed croplands that could lead them to replant their failed crops.

\section{Conclusion and policy recommendations}

The study communities have tremendous ideas to adapt for current and future climate change impacts with a strong motivation to move out of poverty. However, the mere willingness to adopt climate change adaptation strategies was not enough. Their ability to adopt is constrained by many internal and external factors. Rural communities who did not employ adaptation strategies gave many reasons for their failure to adopt. These includes poor or no access to water sources, limited knowledge, and skill, shortage of labour, lack of and/or shortage of farmland, lack of money, lack of information, lack of agricultural extension services, and other institutional factors.

The most significant determinant factors of the choice of crop management strategies were age, farming experience, income, agro-ecology setting, and farmland size. Agro-ecology setting has a significant effect on all adaptation strategies. Due to the soil characteristics, the lowland agro-ecology zones were not suitable for adopting improved seeds. However, the government bodies in the office of agriculture did not realize the problems. This implies, in the process of diffusion of adaptation strategies, climate change adaptation process should require close collaboration and active participation of climate change researchers, decision-makers, policy analysts, the community, and partners. Government policies should strengthen the current adaptation strategies practised by rural community households and support the adoption of crop management strategies. Besides, the less adopted crop management strategies due to financial constraints should be subsidized by government and aid organizations. This study contributes to the academic discourse on climate change impact adaptations by providing empirical evidence to deepen understanding of the barriers and determinants that confronts rural communities in their attempt to implement adaptation strategies to manage the negative impacts of climate change and variability.

\section{Abbreviations}

$d f$ : degree of freedom; HHs: households; HHHs: household heads; NC: not computed; m.a.s.l: metres above sea level; VIF: variance inflation factor.

\section{Authors' contributions}

ZYA designed the data collection tools, conducted fieldwork and analysis, and developed the manuscript. JOA contributed in commenting the data collection tools, recommending data analysis methods, reviewed and made editorial comments on the draft manuscript. IOA contributed in commenting the data collection tools, data analysis methods, reviewed and made editorial comments on the draft manuscript. MTZ contributed to developing the data collection tools, commenting data analysis methods, reviewed, and made editorial comments on the draft manuscript. All authors read and approved the final manuscript.

\section{Author details}

${ }^{1}$ Institute of Disaster Risk Management and Food Security Studies, Bahir Dar University, BahirDar, Ethiopia. ${ }^{2}$ Department of Geography, Faculty of the Social Sciences, University of Ibadan, Ibadan, Nigeria. ${ }^{3}$ Department of Geography and Environmental Studies, Debre Tabor University, Debre Tabor, Ethiopia.

\section{Acknowledgements \\ This study was made possible by the financial support of Pan-African Univer- sity (PAU), a continental initiative of the African Union Commission (AU), Addis Ababa, Ethiopia. Further, authors would like to thank the data collectors and field assistants for their effective coordination, support, and time spent in organizing and conducting successful household interviews. Special thanks to the Dejen District rural communities who willingly volunteered the informa- tion in this study.}

\section{Competing interests}

The authors declare they have no competing interests.

\section{Availability of data and materials}

The datasets used and/or analysed during the current study available from the corresponding author on reasonable request.

\section{Consent for publications}

The authors obtained permission from all participants in Dejen District, to publish their data. 


\section{Ethics approval and consent to participate}

Consent to participate was received from everyone interviewed in Dejen District, Ethiopia. The Pan-African University, Life and Earth Sciences Institute (PAULESI) (including Health and Agriculture), University of Ibadan were informed of the study.

\section{Funding}

This study was sponsored by the Pan-African University (PAU), a continental initiative of the African Union Commission (AU), Addis Ababa, Ethiopia.

\section{Received: 11 November 2017 Accepted: 22 May 2018}

Published online: 05 June 2018

\section{References}

1. WMO. Statement on the status of the global environment, vol. 1152. Geneva: Japan Meteorological Agency, in Cooperation with the World Meteorological Organization; 2015. p. 250

2. FAO. Climate change and food safety: a review. Food Res Int. 2010;43(7):1745-65.

3. Foresight $U$. The future of food and farming. Final project report. London: The Government Office for Science; 2011.

4. Füssel H-M, Klein RJ. Climate change vulnerability assessments: an evolution of conceptual thinking. Clim Change. 2006;75(3):301-29.

5. Rahman MI-U. Climate change: a theoretical review. Interdiscip Descr Complex Syst. 2013;11(1):1-13.

6. Gbetibouo GA. Understanding farmers' perceptions and adaptations to climate change and variability: the case of the Limpopo Basin, South Africa, vol. 849. Washington: The International Food Policy Research Institute; 2009.

7. Segele ZT, Lamb PJ. Characterization and variability of Kiremt rainy season over Ethiopia. Meteorol Atmos Phys. 2005;89(1):153-80.

8. NMA. Climate change national adaptation programme of action (Napa) of Ethiopia. National Meteorological Services Agency (NMA), Ministry of Water Resources, Federal Democratic Republic of Ethiopia, Addis Ababa; 2007.

9. You GJ-Y, Ringler C. Hydro-economic modeling of climate change impacts in Ethiopia. International Food Policy Research Institute (IFPRI); 2010

10. Schröter D, Polsky C, Patt AG. Assessing vulnerabilities to the effects of global change: an eight step approach. Mitig Adapt Strat Glob Change. 2005;10(4):573-95.

11. DDARDO. Dejen District Agricultural and Rural Development Office (DDRDO), Annual Report, East Gojjam zone, Dejen, Ethiopia; 2016.
12. DDEPO. Dejen District Environmental Protection Office (DDEPO), East Gojjam zone, Dejen, Ethiopia; 2016.

13. Yamane T. Statistics: an introductory analysis. New York: Harper and Row; 1967.

14. DDFEDO. Dejen District Finance and Economic Development Office (DDFEDO) Population Projection (DDFED, 2014); 2014.

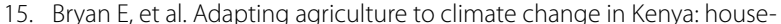
hold strategies and determinants. J Environ Manag. 2013;114:26-35.

16. Abid M, et al. Farmers' perceptions of and adaptation strategies to climate change and their determinants: the case of Punjab province, Pakistan. Earth Syst Dyn. 2015;6(1):225.

17. Agresti A. An introduction to categorical data analysis. 2nd ed. Hoboken: Wiley; 2007.

18. NBE National Bank of Ethiopia. Commercial Banks'Exchange rate; 2016.

19. Kothari CR. Research methodology: methods and techniques. Chennai: New Age International; 2004.

20. SPSS. Statistical Package for the Social Sciences (SPSS). Version20.

21. Kothari GG. Research methodology. 3rd ed. New Delhi: New Age International Publishers; 2014.

22. Bryan E, et al. Adaptation to climate change in Ethiopia and South Africa: options and constraints. Environ Sci Policy. 2009;12(4):413-26.

23. Kithiia J. Climate change risk responses in East African cities: need, barriers and opportunities. Curr Opin Environ Sustain. 2011;3(3):176-80.

24. Peterson C. Fast-growing groundnuts keep Ghana's farmers afloat amid climate shifts. Retrieved July, 2013, vol. 16, p. 2013.

25. IPCC. Climate change: climate change impacts, adaptation and vulnerability. The fourth assessment report of the Intergovernmental Panel on Climate Change. Geneva, Switzerland; 2007.

26. Deressa TT, et al. Determinants of farmers' choice of adaptation methods to climate change in the Nile Basin of Ethiopia. Glob Environ Change. 2009;19(2):248-55.

27. Menberu TZ, Aberra Y. Determinants of the adoption of land management strategies against climate change in Northwest Ethiopia. Ethiop Renaiss J Soc Sci Humanit. 2014;1:93-118.

28. Barungi M, Maonga BB. Adoption of soil management technologies by smallholder farmers in central and southern Malawi. J Sustain Dev Afr. 2011;13(3):28-38

29. Maddison D. The perception of and adaptation to climate change in Africa, vol. 4308. Washington: World Bank Publications; 2007.

30. Nhemachena C, Hassan R. Micro-level analysis of farmers adaption to climate change in Southern Africa. Washington: The International Food Policy Research Institute; 2007.
Ready to submit your research? Choose BMC and benefit from:

- fast, convenient online submission

- thorough peer review by experienced researchers in your field

- rapid publication on acceptance

- support for research data, including large and complex data types

- gold Open Access which fosters wider collaboration and increased citations

- maximum visibility for your research: over $100 \mathrm{M}$ website views per year

At BMC, research is always in progress.

Learn more biomedcentral.com/submissions 